\title{
An Analysis of Host Country Characteristics that Determine FDI in Developing Countries: Recent Panel Data Evidence
}

\author{
Muhammad Tariq Majeed ${ }^{*}$ and Eatzaz Ahmad ${ }^{* *}$
}

\begin{abstract}
This paper analyzes a range of host country characteristics that determine foreign direct investment (FDI) flows to developing countries, using panel data on 72 countries for the period 1970-2008. Keeping in view the endogeneity problem of the chosen host country's characteristics, the model is estimated using the General Method of Moments (GMM) technique. The analysis shows that gross domestic product (GDP), economic growth, and per capita income positively affect FDI-a result consistent with the marketseeking behavior of multinational corporations (MNCs). Furthermore, we find that remittances have a significant and positive impact on FDI. On the other hand, inflation and the balance of payments deficit have negative effects on FDI. MNCs are attracted to host countries that are outward looking and follow trade-promoting policies. This is confirmed by the positive effect of openness on FDI flows to developing countries. The study also finds that the effect of military expenditures on FDI is negative and significant. Finally, our analysis finds that the real exchange rate has a significantly negative impact on FDI.
\end{abstract}

Keywords: Investment, panel data, developing countries, FDI, GMM.

JEL Classification: F21.

\section{Introduction}

Most developing countries experience a shortage of capital, which is reflected in their respective savings-investment and import-export gaps. This implies that developing countries have insufficient savings/foreign exchange to finance their investment needs. To bridge this gap, they need an inflow of foreign capital. Foreign direct investment (FDI) is thus an important source of capital for growth in developing countries.

\footnotetext{
* Lecturer, Department of Economics, Quaid-i-Azam University, Islamabad.

** Professor, Department of Economics, Quaid-i-Azam University, Islamabad.
} 
In the 1960s and 1970s, many countries maintained a cautious and sometimes negative position towards foreign investment. In the 1980s, however, attitudes shifted radically toward a more welcoming policy stance. This change was due mainly to the economic problems facing the developing world. While FDI has surged, other forms of capital flows to developing countries have diminished: Aid has declined continuously as a share of capital inflows since the 1960 s, while commercial loans, a major source of capital flows in the 1970s, have virtually disappeared since the debt crisis of the 1980s.

It is generally assumed that FDI contributes to economic growth and restructuring in developing economies. However, there is increasing competition between developing (and developed) countries to attract FDI flows to enter into, or consolidate their position within, an increasingly integrated world production, trading, and investment system. In this study, we focus on the inflow of FDI, using panel data for 72 developing countries. In order to overcome constraints to the supply of FDI, we aim to identify the determinants of FDI inflows.

The rest of the paper is organized as follows: Section II provides a literature review. Section III explains the model and framework of analysis used. Section IV describes the dataset and construction of variables. Section $\mathrm{V}$ presents our findings from the empirical analysis, and Section VI presents a summary with some policy implications.

\section{Literature Review}

The earlier literature describes the determinants of FDI theoretically without giving empirical results (for example, Lall 1978). Later studies based on empirical analysis have increasingly appeared in the literature. These studies differ from earlier studies on the basis of theory. Initially, pure economic theory, i.e., that of international trade and the theory of the firm, were adopted as the theoretical base for empirical studies of FDI determinants. These theories assume the presence of perfect competition and an identical production function, and attribute FDI flows to the difference in interest rates across countries. However, this does not explain the large volume of FDI flows across countries. ${ }^{1}$

Recent theories, as a base for FDI and in particular the growth of multinational corporations (MNCs), have turned to explanations based on

\footnotetext{
${ }^{1}$ FDI flows to developing countries increased manifold, rising from US\$33.7 billion in 1990 to US\$172.9 billion in 1997 (Government of Pakistan 2000/01).
} 
market imperfections, oligopolistic interdependence, and monopolistic advantage. It is assumed that, for FDI to take place, a necessary condition is that investing firms have some monopolistic advantage that local competitors do not have.

Wang and Swain (1995) explore the factors that explain foreign capital inflow into Hungry and China during the period 1978-92. More specifically, they analyze the relative importance of market size, cost of capital, labor costs, tariff barriers, exchange rates, import volumes, and economic growth in OECD countries within the framework of a oneequation mode1. ${ }^{2}$ They estimate their chosen model using Ordinary Least Squares (OLS) regressions; the findings of their study suggest that the size of the host country's market plays a positive role, while the cost of capital variable is negatively correlated with investment inflows. They find little evidence to support classical hypotheses concerning tariff barriers and import variables.

In a survey article, De Mello (1997) discusses more recent developments in the literature on the determinants of FDI and the impact of inward FDI on growth in developing countries. The study argues that the policy regime of host countries is a potentially important FDI determinant. The recent literature has provided policymakers in developing countries with more adequate tools and more accurate benchmarks for cross-country comparisons and policy evaluation. Foreign investors are motivated primarily by international rent seeking under standard profit maximizing assumptions. The most important factors explaining FDI inflows into developing countries in recent years are (i) the foreign acquisition of domestic firms in the process of privatization, (ii) the globalization of production, and (iii) increased economic and financial integration.

De Mello (1997) also presents a brief summary of case studies such as O’Sullivan (1993), Bajorubio and Sovilla-Rivero (1994), Wang and Swain (1995), Milner and Pentecost (1996), and Lee and Mansfield (1996), which specify the exchange rate, inflation, domestic expenditures, and trade ratio as important determinants of FDI.

\footnotetext{
${ }^{2}$ Most of these independent variables, except average growth rates and the cost of capital in home countries, can be found in Aggarwal's (1980) study. Many earlier empirical studies (for instance, Petrochilos 1989 and Huang 1992) have supported Jorgenson's (1963) hypotheses that the cost of capital determines FDI, while others suggest that the faster growth of home countries has played a positive role in driving FDI in host countries (Jeon 1992).
} 
Using a panel dataset for sub-Saharan Africa (SSA) countries, Asiedu (2002) explores the determinants of FDI and examines why SSA has been relatively unsuccessful in attracting FDI in spite of policy reforms. The results of this study indicate that better infrastructure and a higher return on investment has a positive impact on FDI in non-SSA countries, while there is no significant impact on FDI in SSA countries. The coefficient on openness to trade is conducive to FDI in both SSA and non-SSA countries. However, the marginal benefit from increased openness is lower for SSA countries. The author concludes that factors that determine FDI in the developing world have a different impact on FDI in SSA countries. The results of this study are based on the OLS estimation technique, which does not address the problem of endogeneity.

Using a panel dataset for 20 developing countries during the 1990s, Sekkat and Varoudakis (2007) assess the importance of openness, infrastructure availability, and sound economic and political conditions in attracting FDI. Their analysis shows that openness constitutes a key factor in attracting FDI to an economy. Their findings also highlight the importance of investment climate (infrastructure, economic, and political environment) in increasing a country's attractiveness with respect to FDI. The authors suggest that an improvement in business climate can result in a larger increase in FDI inflows relative to a greater degree of openness.

Botric and Skuflic (2006) analyze FDI determinants in southeast European countries during the period 1996-2002. The authors use GLS regression analysis on a pooled sample. Their analysis shows that the trade regime (openness) and density of infrastructure exert a significantly positive influence on FDI. However, the study does not find that market-seeking determinants (GDP, per capita GDP, GDP growth, population) have any significant or robust effect on FDI.

Kok and Ersoy (2009) investigate the determinants of FDI in 24 developing countries. They use OLS and cross-sectional seemingly unrelated regression (SUR) econometric techniques: the former for the period 19382005 and the latter for the period 1976-2005. They find that total debt service/GDP and inflation have a significant negative influence on FDI while per capita GDP growth, gross capital formation, trade openness, and the presence of telephone main lines have a positive effect on FDI.

Onyeiwu and Shrestha (2004) use fixed and random effects models to explore the determinants of 29 African countries for the period 1975 to 1999. This study identifies economic growth, openness, inflation, international reserves, and natural recourses as significant determinants of 
FDI flows to Africa. The authors point out that these factors are conducive to FDI regardless of whether the impact of country- and time-specific effects on FDI is stochastic or fixed.

Estimating a cross-sectional econometric mode1, Demirhanand and Masca (2008) explore the determinants of FDI inflows in 38 developing countries for the period 2000-2004. They find that the positive and significant factors affecting FDI include income per capita growth rate, telephone main lines, and degree of openness. The inflation rate and tax rate have a negative sign and are statistically significant. Factors that emerge as insignificant in determining the inflow of FDI are labor cost and risk.

Ahmad and Malik (2009) analyze the factors that effect FDI, domestic investment, and growth, using a panel dataset for 35 developing countries for the period 1970-2003. Their findings indicate that the effect of FDI on economic growth is insignificant while the effect of domestic investment is positive and highly significant, implying that it has a complementary relationship with FDI. The authors argue that this complementary relationship indicates that the presence of domestic investment is an indicator of profit-making opportunities and the willingness of domestic investors to develop complementary industries that are important for successful long-term business ventures for foreign investors, e.g., the development of parts industries to support foreign automobile companies in developing countries.

Ahmad and Malik (2009) specify six determinants of FDI: (i) GDP, (ii) per capita income, (iii) domestic investment, (iv) openness, (v) exchange rate, and (vi) education. The effect of market size in this study emerges as insignificant while the effect of openness is positive and significant. The authors conclude that a small but open economy is more attractive to foreign investors than a large but relatively closed economy. Their analysis reports a negative and statistically significant coefficient on the real exchange rate, implying that real depreciation decreases the relative prices of goods in the host country and makes it more economical for MNCs to make a country their production base rather than an export target. Finally, the impact of the literacy rate is positive and statistically significant for attracting FDI.

In the empirical literature, FDI determinants have been examined at both micro- and macro-levels. Studies focus mainly on the following variables: market size, openness, exchange rate, cost of labor and infrastructure variables. Many variables such as remittances, official development assistance, dependency ratio, and military expenditures, remain, to our knowledge, unnoticed. At the same time, most studies do 
not incorporate the maximum possible number of developing countries in panel data estimation. The existing empirical literature on FDI also suffers from the problem of endogeneity because most studies use the OLS method, which provides biased results. Even though some studies control for cross-country fixed effects and random effects, these econometric techniques do not control for endogeneity.

This study fills the existing gaps in the literature by using the GMM econometric technique for the period 1970-2008. We also look for those country characteristics that are not emphasized in the existing literature for a large set of developing countries.

\section{Methodology}

In this section, we formulate a framework of analysis to determine the effect of various factors on FDI in the developing countries that constitute our sample. The underlying objective is to explain the rationale for FDI. It is generally believed that MNCs invest in those countries where they expect higher rates of return. We introduce a variety of host country characteristics that determine the profits of firms on FDI.

\section{Market Size}

The market size hypothesis argues that inward FDI is a function of the size of the host country market, usually measured by GDP and per capita income. We use GDP and per capita income as a proxy for market size. High demand, prospects of economies of scale, good economic health, and absorptive capacity are factors that give a "green light" to foreign investors. The combined effect of such factors can be captured by market size. Larger market size is expected to have a positive effect on FDI. This positive effect is supported in the literature by Reuber (1973), Schneider and Fry (1985), Wheeler and Mody (1992), and Zhang and Markusen (1999).

\section{Growth of GDP}

Market size exhibits existing demand in an economy while growth represents future potential. A high level of economic growth is a strong indicator of market opportunities. The growth of the host market is deemed significant for expansionary direct investment (Clegg and Scott-Green 1998). Growth is also important because higher rates of economic growth are usually associated with an increase in the profitability of corporations (Gold 1989). There is relatively little support in the existing literature for this 
determinant of FDI when compared to the market size variable (Goldberg 1972, Scaperlanda and Balough 1983, Culem 1988, and Clegg 1995).

\section{Remittances}

Barajas, et al (2009) evaluate different theories of the impact of remittances in developing countries. First, remittances are a source of physical and human capital accumulation because they finance directly the cost of investment and support the schooling of younger household members. Second, recipient households substitute unearned income (remittances) for labor income because remittances are an easy source of income, implying that remittances are inversely related to labor force participation. Third, in general, remittance flows stimulate household spending, especially on products that are produced by foreign companies. Moreover, the bandwagon effect works as a multiplier on the demand for various products. As we will control for domestic investment and the dependency ratio in explaining FDI, we expect the effect of remittances to occur through household general spending and human capital accumulation. Having said this, we expect remittances to have a positive effect on FDI.

\section{Exchange Rate}

The exchange rate affects FDI in several ways. Froot and Stein (1991) have discussed the relative wealth effect of exchange rates. A rise in the exchange rate in terms of the host country's currency over the home country's currency implies a depreciation of the former's currency. A real depreciation of the host country's currency favors the home country's purchases of host country assets, and therefore leads to an increase in inward FDI in the host country. Gushman $(1985,1987)$ and Culem (1988) emphasize the effect of exchange rate changes on relative labor cost. A real depreciation of the host country's currency allows home country investors to hire more labor for a given amount of the home country's currency, and is therefore associated with an increase in inward FDI in the host country. The findings of Klein and Rssengren (1994) support the significance of the relative wealth effect but fail to support the relative labor cost effect.

\section{Balance of Payments Deficit}

The expected sign of the coefficient of balance of payments is negative because it indicates that a larger deficit means that a country is living beyond its means. Foreign investors are likely to sense the danger of restrictions on free capital movement, which would make it difficult to transfer a firm's profits (Schneider and Frey 1985). 


\section{External Debt Burden}

This shows external imbalances; a higher debt burden creates constraints not only in terms of new private lending but also in terms of FDI flows (Nunnenicamp 1991). Hence, it is expected to discourage FDI, and the coefficient on external debt is exposed to be negative.

\section{Inflation Rate}

Another important determinant of FDI is the inflation rate, which exerts a negative influence on the profitability of FDI because it increases the user cost of capital (De Mello 1997). A high rate of inflation results from imprudent fiscal and monetary policies, such as persistent budget deficits, excessive money supply and a poorly managed exchange rate regime. It also reflects a country's macroeconomic instability, which in turn discourages the flow of FDI (Calvo, et al 1996). In cross-country studies, inflation is used as a proxy to capture macroeconomic instability, which is strongly correlated with political instability.

\section{Openness}

A greater degree of openness encourages a higher flow of FDI, primarily because most MNCs are export-oriented. They tend to acquire the benefits of export expansionary policies and import machinery for production from their home country. We expect this variable to have a positive effect on FDI. Kravis and Lipsey (1982) report the positive impact of host countries' degree of openness on the location decisions of MNCs.

\section{Military Expenditure}

A large proportion of the budget reserved for defense expenditures may imply future uncertainty, lower development expenditures, and wasted resources. Such factors create an adverse climate for investment. Moreover, the weapons accumulation race may adversely affect foreign relations. Hence, we expect military expenditures to have a negative influence on FDI. In developing countries, sectors regarded as strategic and related to national defense or sovereignty are frequently targeted by protectionist policies. These polices tend to distort social and private returns to capital and hence reduce the efficiency of FDI (De Mello 1999). 


\section{Domestic Investment}

This may be a substitute or complement for FDI depending on the investment climate of the host country and the types of FDI. However, the literature shows mixed results. When domestic investment increases, the marginal productivity of investment decreases; if the marginal productivity of FDI also decreases, then the relationship will be a substituting one. This can happen when domestic investment dominates the production sector. On the other hand, if the marginal productivity of FDI increases, then relationship will be complementary. This can happen when domestic investment dominates the infrastructure sector. Furthermore, if domestic investors and foreign investors compete for joint ventures then this relationship will be a substituting one (see, for example, Buffie 1993).

\section{Credit Facilities}

Better credit facilities improve the investment climate for domestic investors, implying that there could be less room left for foreign investors. Hence, we expect this variable to have a negative influence on FDI.

\section{Official Development Assistance}

Official development assistance expenditures are indicators of development activities. Such expenditures favorably determine infrastructure and also indicate a country's good terms with international institutions; this builds confidence among foreign investors. Luger and Shetty (1985) have presented suggestive evidence on this aspect. ${ }^{3}$

\section{Communication Facilities}

A society is taken as developed and industrialized if it has a sophisticated and widespread communication system. The presence or lack of communication facilities shapes the boundaries of nations, states, and local governments (Coughlin, Terza, and Arromdee 1991).

\section{Dependency Ratio}

A high dependency ratio implies a vacuum of skilled labor. In developing countries, higher dependency ratios present a great concern. A single person covers the living expenditures of a large family. Such persons are likely to overwork, leading to an adverse effect on their health and

\footnotetext{
${ }^{3}$ See for more detail Luger and Shetty (1985).
} 
productivity. We can expect the dependency ratio to have a negative influence on investment decisions.

\section{Model}

The model we have developed takes into account those factors that play an important role in the determination of FDI in developing countries. We have a single equation model:

$$
\mathrm{FDI}_{\mathrm{it}}=\mathrm{f}\left(\mathrm{PCY}_{\mathrm{it}}, \mathrm{X}_{\mathrm{it}}, \ldots \mathrm{X}_{\mathrm{nt}}, \xi_{\mathrm{it}}\right)
$$

where $\mathrm{FDI}_{\mathrm{it}}$ represents the dependent variable, FDI, while $\mathrm{X}_{\mathrm{it}}$ represent the vectors of exogenous variables. The subscript $i(=1, \ldots \ldots n)$ represents the country and $\mathrm{t}(=1, \ldots \mathrm{T})$ the period of time in years. The variable $\mathrm{PCY}_{\mathrm{it}}$ represents per capita income. Notice that the vectors $\mathrm{X}_{\mathrm{it}}$, generally include some overlapping variables. The specified equation for FDI is as follows:

$$
\begin{aligned}
\text { FDI }_{i t}= & f\left(G_{i t}, \operatorname{PGDP}_{i t}, G R O W_{i t}, \mathrm{REM}_{\mathrm{it}}, \mathrm{EXCH}_{\mathrm{it}}, \mathrm{BOP}_{\mathrm{it}}, \mathrm{ED}_{\mathrm{it}},\right. \\
& \left.\mathrm{INF}_{\mathrm{it}}, \mathrm{OPEN}_{\mathrm{it}}, \mathrm{ME}_{\mathrm{it}}, \mathrm{DI}_{\mathrm{it}}, \mathrm{CRED}_{\mathrm{it}}, \mathrm{OD}_{\mathrm{it}}, \mathrm{TP}_{\mathrm{it}}, \mathrm{DEP}_{\mathrm{it}},\right)
\end{aligned}
$$

where

$$
\begin{aligned}
& \text { FDI = foreign direct investment as a percentage of GDP, } \\
& \text { GDP = gross domestic product in constant prices in 2000, } \\
& \text { PGDP = per capita GDP, } \\
& \text { GROW = annual percentage growth rate of GDP, } \\
& \text { REM = workers' remittances as a percentage of GDP, } \\
& \mathrm{EXCH}=\text { real exchange rate (obtained by multiplying the nominal } \\
& \text { exchange rate with US consumer price index (CPI) and } \\
& \text { then divided by domestic CPI), } \\
& \text { BOP = balance of payments as a percentage of GDP, } \\
& \mathrm{ED}=\text { external debt as a percentage of GDP, } \\
& \text { INF = inflation, consumer prices (as an annual percentage), } \\
& \text { OPEN = openness measured as exports plus imports as a percentage } \\
& \text { of GDP, } \\
& \mathrm{ME}=\text { military expenditures as percentage of GDP, } \\
& \text { DI = domestic investment as a percentage of GDP, }
\end{aligned}
$$




$$
\begin{aligned}
\text { CRED = } & \text { credit facilities available to domestic sector as a percentage } \\
& \text { of GDP, } \\
\mathrm{OD}= & \text { official development assistance as a percentage of GDP, } \\
\mathrm{TP}= & \text { number of telephones per } 1,000 \text { people, } \\
\mathrm{DEP}= & \text { dependency ratio measured as the percentage of } \\
& \text { nonworking population to the working population. }
\end{aligned}
$$

\section{Data and Estimation Procedure}

Data for this study have been taken from World Development Indicators (WDI) 2009. A sample of 150 countries was selected, of which 72 were chosen, for which data on most of the variables were available for at least 16 years. All variables are measured in US dollars at constant prices.

Gross FDI is measured as a percentage of GDP and refers to the inflows of FDI recorded in the balance of payments financial account. The official exchange rate is measured as the number of local currency units per US dollar, period average. The official exchange rate refers to the actual principal exchange rate and is an annual average based on monthly averages determined by country authorities or on rates determined largely by market forces in the legally sanctioned exchange market. We converted the nominal exchange rate into the real exchange rate by multiplying the former by the US CPI and then dividing it by the domestic CPI.

The balance of payments is the current account balance, and includes the credit minus debit of goods, income, and current transfers as a percentage of GDP. Total external debt is measured as a percentage of GDP, and includes the debt owed to nonresidents repayable in foreign currency, goods, or services. Total external debt is the sum of public, publicly guaranteed, and private nonguaranteed long-term debt, use of International Monetary Fund (IMF) credit, and short-term debt. Short-term debt includes all debt with an original maturity of 1 year or less and interest in arrears on long-term debt.

The variable openness is measured as exports plus imports, divided by GDP. It measures the degree of trade liberalization. Military expenditures data from SIPRI are derived from the NATO definition, which includes all current and capital expenditures on the armed forces, including peacekeeping forces, defense ministries and other government agencies engaged in defense projects, paramilitary forces (if these are judged to be trained and equipped for military operations), and military space activities. Such expenditures include military and civil personnel, including retirement 
pensions of military personnel and social services for personnel, operation and maintenance; procurement; military research and development, and military aid (in the military expenditures of the donor country).

Gross domestic investment is measured as a percentage of GDP. It consists of outlays on additions to the economy's fixed assets plus net changes in the level of inventories. Fixed assets include land improvements (fences, ditches, drains, and so on), plant, machinery, and equipment purchases, and the construction of roads, railways, etc., including commercial and industrial buildings, offices, schools, hospitals, and private residential dwellings. Inventories are stocks of goods held by firms to meet temporary or unexpected fluctuations in production or sales.

Credit to the private sector is measured as a percentage of GDP. It refers to financial resources provided to the private sector - such as through loans, purchases of nonequity securities, trade credits, and other accounts receivable - that establish a claim for repayment. In some countries, these claims also include credit to public enterprises.

Official development assistance and net official aid record the actual international transfer by the donor of financial resources or of goods or services valued at the cost to the donor, less any repayments of loan principal during the same period. Aid dependency ratios are computed using values in US dollars converted at official exchange rates.

\section{Estimation Technique}

The use of pooled time-series and cross-sectional data provide a large sample that is expected to yield efficient parameter estimates. In this study, we use the GMM estimation technique which has been developed for dynamic panel data analysis, and introduced by Holtz-Eakin, et al (1990), Arellano and Bond (1991), Arellano and Bover (1995), and Blundell and Bond (1997).

The GMM technique controls for the endogeneity of all explanatory variables, allows for the inclusion of lagged dependent variables as regressors, and accounts for unobserved country-specific effects. Following the standard convention in the literature, the equations are estimated by using the lagged first difference as an instrument (Ahmad and Malik 2009).

\section{Empirical Results and Interpretation}

In this section we report the empirical results based on pooled data for 72 developing countries for the period 1970-2008. We select a large set 
of developing countries for empirical investigation. The results of the estimation are presented in Tables-1 and 2.

Table-1: Parameter Estimates of GMM

\begin{tabular}{|c|c|}
\hline Variables & Parameter Estimates \\
\hline PCY & $\begin{array}{c}0.0001 \\
(1.77)^{* * *}\end{array}$ \\
\hline GDP & $\begin{array}{c}1.16 \mathrm{E}-12 \\
(2.28)^{* * *}\end{array}$ \\
\hline GROW & $\begin{array}{c}0.26 \\
(2.76)^{*}\end{array}$ \\
\hline BOP & $\begin{array}{c}-5.59 \mathrm{E}-11 \\
(-3.16)^{*}\end{array}$ \\
\hline ED & $\begin{array}{c}5.95 \mathrm{E}-05 \\
(-0.03)\end{array}$ \\
\hline OPEN & $\begin{array}{l}0.008 \\
(2.44)^{* *}\end{array}$ \\
\hline DI & $\begin{array}{c}-0.021 \\
(-1.82)^{* * *}\end{array}$ \\
\hline CRED & $\begin{array}{l}0.003 \\
(0.85)\end{array}$ \\
\hline OD & $\begin{array}{c}1.50 \\
(1.10)\end{array}$ \\
\hline $\mathbf{T P}$ & $\begin{array}{c}0.054 \\
(3.22)^{*}\end{array}$ \\
\hline INF & $\begin{array}{l}-0.0016 \\
(-1.78)^{* * *}\end{array}$ \\
\hline DEP & $\begin{array}{l}-7.63 \mathrm{E}-10 \\
(-1.70)^{* * *}\end{array}$ \\
\hline REM & $\begin{array}{c}0.044 \\
(1.87)^{* * *}\end{array}$ \\
\hline ME & $\begin{array}{c}-0.118 \\
(-2.25)^{* *}\end{array}$ \\
\hline No. of Countries & 72 \\
\hline $\mathbf{R}^{2}$ & 0.60 \\
\hline J Statistics & 7.41 \\
\hline $\mathbf{D} \mathbf{W}$ & 1.68 \\
\hline
\end{tabular}

Note: The t-statistics are given in parentheses $(*),(* *)$, and $(* * *)$ indicating statistical significance at $1 \%, 5 \%$, and $10 \%$ levels, respectively. 
The variables that are statistically significant in the GMM estimation include GDP, per capita income, GDP growth rate, remittances, the real exchange rate, inflation, military expenditures, trade openness, balance of payments, domestic investment, dependency ratio, and communication. Variables that are insignificant include external debt, credit available to the private sector, and official development assistance. Although insignificant, these variables obtain the correct signs in relation to FDI.

One of the most important determinants found to have a significant favorable effect on FDI in all the estimated equations is per capita GDP. It is the most commonly used proxy for market size. This finding emphasizes the necessity of a large market for the efficient utilization of resources and exploitation of economies of scale. A larger market offers higher demand and absorptive capacity in an economy and attracts foreign investors. MNCs are particularly attracted by large markets because they do not have to reship most of their products to parent countries. Once a foreign firm is established in an economy, it can take oligoplistic advantage of its large size, technical knowhow, and other facilities. These relative advantages result in higher profits. Thus, market size helps perpetuate FDI.

Unlike some empirical studies ${ }^{4}$, economic growth is also highly significant in relation to FDI. Our results are thus consistent with prior expectations. Growth is important because higher rates of economic growth are usually associated with an increase in the profitability of corporations. ${ }^{8}$ High economic growth rates in host countries, apart from the presence of a large domestic market, usually indicate credible and stable macroeconomic policies that attract foreign capital.

Remittances capture the market-seeking motivation of MNCs, and the variable emerges as positive and significant. Remittances are an easy source of income for recipient households and receivers spend this unearned income on various products, including those produced by foreign companies. Although remittances are also a source of capital accumulation, we have already controlled for the effect of domestic investment, which is negative and significant in developing countries over the study period. This finding indicates that the relationship between FDI and domestic investment is not complementary.

\footnotetext{
${ }^{4}$ Our findings on the insignificant growth rate are in line with those presented by Clegg (1995) and Clegg and Scott-Green (1998). Findings on the significant growth rate are in line with Root and Ahmad (1979).

${ }^{8}$ See Gold (1989) p. 213.
} 
The variable official development assistance is considered favorable for FDI in the literature. Our estimates, however, show that this association is insignificant but positive. The reason for its insignificance may be the low level of structural development in the least developed countries, which dominate the sample, and may be due to the lack of revenues and high expenditures for debt servicing and defense.

The effect of the balance of payments deficit is significant with a negative sign, perhaps because it implies that a country is living beyond its means. Furthermore, it indicates that a country is facing macroeconomic instability. In such countries, governments and government polices are not stable and consistent, causing foreign investors to hesitate when investing. The effect of external debt on FDI is negative but insignificant.

Another important determinant of FDI is the inflation rate, which is found to be negative and significant. This is consistent with De Mello (1997), who argues that inflation exerts a negative influence on the profitability of FDI because it increases the user cost of capital. A high rate of inflation results from imprudent fiscal and monetary policies, such as persistent budget deficits, excessive money supply, and a poorly managed exchange rate regime. It also reflects macroeconomic instability in a country that discourages the flow of FDI.

Communication facilities are measured in terms of the number of telephones. The effect of this facility on FDI is significant and has a positive sign. Telephones are the main source of communication in this globalized era and integrate markets within and across countries. A wide network of telecommunication facilities creates a market-friendly environment and exerts a positive influence on FDI inflows in developing countries.

The labor force variable is an important determinant of FDI. If we analyze only the size of the labor force, this may obscure the true results because the quality of the labor force is also important. Keeping this in view, we use the dependency ratio as a proxy for labor quality because a higher dependency ratio implies a lower quality of labor and vice versa. The effect of the dependency ratio is significantly negative in explaining FDI flows. This variable may reflect the general phenomenon of single persondependent families in developing countries. Such situations exert a negative influence on the productivity of the labor force. Our empirical results are consistent with this phenomenon.

The effect of openness is highly significant with a positive sign. Trade openness identifies the magnitude of trade liberalization and is 
important because developing countries are used as a terminal. MNCs are attracted to countries with a location advantage, with the aim of exporting their products to a large market. Fewer trade barriers make the import of raw materials, such as plant machinery, convenient. On the other hand, MNCs can also easily export their intermediate and final products. Moreover, due to liberalization policies, MNCs can also take advantage of export promotion facilities. With these factors in mind, we can conclude that our positive relation between openness and FDI is theoretically sound.

\section{Table-2: Parameter Estimates of GMM}

\begin{tabular}{lc}
\hline Variables & Parameter Estimates \\
PCY & 0.0001 \\
GDP & $(1.63)^{* * * *}$ \\
& $1.26 \mathrm{E}-12$ \\
GROW & $(2.37)^{* *}$ \\
EXCH & 0.30 \\
& $(2.79)^{*}$ \\
BOP & $-3.00 \mathrm{E}-05$ \\
& $(-2.37)^{* *}$ \\
ED & $-5.59 \mathrm{E}-11$ \\
& $(-3.19)^{*}$ \\
OPEN & 0.0007 \\
& $(-0.33)$ \\
DI & 0.009 \\
CRED & $(2.82)^{*}$ \\
& -0.030 \\
OD & $(-2.17)^{* *}$ \\
TP & 0.002 \\
& $(0.51)$ \\
INF & 0.98 \\
& $(0.65)$ \\
DEP & 0.048 \\
& $(2.60)^{*}$ \\
REM & -0.0016 \\
& $(-1.78)^{* * *}$ \\
ME & $-8.25 \mathrm{E}-10$ \\
No of Countries & $(-1.70)^{* * *}$ \\
R Statistics & 0.030 \\
D W & $(1.79)^{* * *}$ \\
& -0.131 \\
& $(-2.30)^{* *}$ \\
& 72 \\
& 0.61 \\
& 4.84 \\
& 1.75 \\
\hline
\end{tabular}

Note: The t-statistics are given in parentheses $(*),(* *)$, and $(* *)$ and indicate statistical significance at $1 \%, 5 \%$, and $10 \%$ levels, respectively. 
In Table- 2 we control for the real exchange rate, which is a key factor in investment decisions by foreign investors. This study finds that the real exchange rate has a negative and significant effect on FDI. The real exchange rate has been included to capture the relative wealth effect and relative labor cost effect; the former implies that a real depreciation of the host country's currency favors the home country's purchases of host country assets, while the latter implies that a real depreciation of the host country's currency allows home country investors to hire more labor for a given amount of the home country's currency.

This result is consistent with Froot and Stein (1991) and Ahmad and Malik (2009). The negative coefficient implies that a real depreciation decreases the relative prices of goods in the host country and makes it more economical for MNCs to make a country their production base. Here, we add another line of reasoning while interpreting real exchange rate depreciation: it also attracts MNCs with the motive of using developing countries as an export platform because real depreciation makes exports more competitive in the international market. This result supports Gushman $(1985,1987)$ and Culem (1988) who emphasize the effect of exchange rate changes on relative labor cost. Real depreciation of the host country's currency allows home country investors to hire more labor for a given amount of the home country's currency, and is therefore associated with an increase in inward FDI into the host country.

We apply the Wald test to the various null hypotheses involving sets of regression coefficients. The results are shown in Table- 3 . The $\mathrm{p}$-value indicates that this analysis rejects the null hypothesis that the regression coefficients of all variables in the FDI equation are equal to zero. We cannot reject the null hypothesis that official development assistance does not affect FDI. The same exercise has been done for the trade openness variable in the model and the test results confirm the significance of trade openness in the model. Similarly, the null hypotheses that the external debt burden and macroeconomic instability do not affect FDI inflows in developing countries can also be rejected. 
Table-3: Results of Wald Test on Parametric Restrictions

\begin{tabular}{lcc}
\hline \multicolumn{1}{c}{ Null Hypotheses } & $\begin{array}{c}\text { Chi-Square } \\
\text { Statistic }\end{array}$ & $\begin{array}{c}\text { Computed Rejection } \\
\text { Probabilities }\end{array}$ \\
\hline $\begin{array}{l}\text { Regression coefficients of all the } \\
\text { variables in the FDI equation are }\end{array}$ & 1254.469 & 0.000 \\
equal to zero \\
$\begin{array}{l}\text { Regression coefficients of the } \\
\text { market seeking variables in the } \\
\text { model are equal to zero }\end{array}$ & 87.65 & 0.000 \\
$\begin{array}{l}\text { Regression coefficient of the trade } \\
\text { openness variable in the model is } \\
\text { equal to zero }\end{array}$ & 5.944 & 0.015 \\
$\begin{array}{l}\text { Regression coefficient of } \\
\text { macroeconomic instability variable } \\
\text { in the model is equal to zero }\end{array}$ & 3.152 & 0.076 \\
$\begin{array}{l}\text { Regression coefficient of the } \\
\text { official development assistance in } \\
\text { the model is equal to zero }\end{array}$ & 1.226 & 0.268 \\
$\begin{array}{l}\text { Regression coefficients of the } \\
\text { financial burden variables (external } \\
\text { debt burden, military expenditures } \\
\text { and BOP deficits) are equal to } \\
\text { zero }\end{array}$ & 18.4858 & \\
\hline
\end{tabular}

\section{Conclusion}

The objective of this study was to determine those host country characteristics that are important in determining the location decisions of MNCs in developing countries. For this purpose we selected panel data for 72 developing countries for the period 1970-2008. The data were taken from the World Development Indicators (WDI) 2009. The GMM model was used to estimate the potential determinants of FDI based on panel data. A number of conclusions can be drawn from the study and are summarized below.

The host country characteristics that are statistically significant and attractive to MNCs are per capita income, GDP, GDP growth rate, remittances, trade openness, and communication facilities. Characteristics that exert a negative influence on FDI flows to developing countries include 
the real exchange rate, inflation, military expenditures, balance of payments, domestic investment, and the dependency ratio. Variables that are insignificant are external debt, credit to the private sector, and official development assistance. Although these variables are insignificant, they obtain the correct signs in relation to FDI.

The variable PGDP (per capita income), which can be used as a proxy for market size, turned out to be positive and significant. The coefficient of the growth rate is also significant and positive. The growth variable is important because higher rates of economic growth are usually associated with an increase in the profitability of MNCs. Remittances are used as a new variable representing market size and emerge as positive and significant in explaining flows to developing countries. Hence, most of the variables that were employed to capture the market-seeking motive of MNCs emerge as significant, implying that the presence of large markets is an important factor driving foreign capital into the developing world.

Trade openness in developing countries indicates the extent to which the borders of a country are free from restrictions on imports and exports; it is also conducive to attracting FDI. The impact of communication facilities is also significantly positive in explaining FDI flows. Such facilities are helpful in exploring access to new markets. The coefficient of official development assistance is positive although insignificant in explaining FDI flows.

The variables balance of payment (BOP) deficit and inflation have a negative impact on FDI inflows. High inflation rates and persistent deficits in a country's BOP mean that it is suffering from macroeconomic and financial problems. The government is thus likely to spend less on development activities and increase the debt burden and import duties, causing a negative effect on foreign investment.

Similarly, the coefficient of military expenditure is significant and has a negative sign. A country with high military expenditures will attract less FDI. High military expenditures may indicate that a country is spending less on economic development. This may lead to public discontent, cuts in development expenditure, and macroeconomic instability, as well as causing foreign investors to suspect hurdles to investment, leading to lower FDI.

The coefficient of domestic investment is negative and significant, implying that the relationship between domestic investment and FDI is not complementary. Arguably, domestic investment dominates the production sector instead of infrastructure, which is consistent with Buffie (1993) who 
argues that domestic investors and foreign investors compete for joint ventures. The coefficient on the dependency ratio is also negative and significant, perhaps because high dependency ratios adversely affect the productivity of the labor force, which in turn exerts a negative influence on FDI.

Finally, this analysis finds a negative and statistically significant coefficient of real exchange rates, possibly because real depreciation decreases the relative price of goods in the host country and makes it more economical for MNCs to make a country its production base and use it as an export platform.

The policy implications that we offer are:

- It is of critical importance that a country maintains a high and sustainable economic growth rate. The study shows that a sustainable growth patterns attract FDI.

- Developing countries can attract greater FDI inflows by removing artificial barriers and controls on exports and imports. An open and export-oriented policy can be promoted by lowering tariffs and allowing the free mobility of capital.

- Widening the net of communication facilities is also instrumental in attracting FDI inflows. To this end, subsidies could be provided to the telecommunications sector. 


\section{References}

Aggarwal, J.P. (1980). Determinants of FDI: A Survey. Weltwirtschaftliches Archive, 116, 739-773.

Ahmad, E., and Malik, A. (2009). Financial Sector Development and Economic Growth: An Empirical Analysis of Developing Countries. Journal of Economic Cooperation and Development, 30(1), 17-40.

Arellano, M., and Bond, S.R. (1991). Some Tests of Specification for Pane1 Data: Monte Carlo Evidence and an Application to Employment Equations. Review of Economic Studies, 58(2), 277-297.

Arellano, M. and Bover, O. (1995). Another Look at the Instrumental Variable Estimation of Error Components Models. Journal of Econometrics, 68(1), 29-52.

Asiedu, E. (2002). On the Determinants of Foreign Direct Investment to Developing Countries: Is Africa Different? World Development, 30(1), 107-119.

Bajorubico, O. and Sosvilla-Rivero, S. (1994). An Economatric Analysis of FDI in Spain. Southern Economic Journal, 61, 104-120.

Barajas, A., Chami, R., Fullenkamp, C., Gapen, M., and Montiel, P. (2009). Do Workers' Remittances Promote Economic Growth? IMF Working Paper 09/153, Washington: International Monetary Fund.

Bartik, T. J. (1985). Business Location Decisions in the United States: Estimates of the Effects of Unionization, Taxes, and Other Characteristics of States. Journal of Business and Economic Statistics, 3, 14-22.

Blundell, R. W. and Bond, S.R. (1998). Initial Conditions and Moment Restrictions in Dynamic Pane1 Data Models. Journal of Econometrics, 87, 115-143.

Botric, V., and Skuflic, L. (2006). Main Determinants of Foreign Direct Investment in the Southeast European Countries. Transition Studies Review, 13(2), 359-377. 
Buffie, S.E. (1993). Direct Foreign Investment, Crowding out and Underemployment in the Domestic Economy. Oxford Economic Paper, 45, 639-667.

Calvo, G.A., Leiderman, L., and Reinhart, C.M. (1996). Inflows of Capital to Developing Countries in the 1990s. Journal of Economic Perspectives, 10, 123-139.

Carlton, D. W. (1983). The Location and Employment Choices of New Firms: An Econometric Model with Discrete and Continuous Endogenous Variables. Review of Economics and Statistics, 65, 440490.

Clegg, J. (1995). The Determinants of United States Foreign Direct Investment in the European Community: A Critical Reappraisal. Paper Presented at the 21st Annual Conference of the European Business Academy, University of Urbino.

Clegg, J. and S. Scott-Green, 1998, "The Determinants of Japanese Foreign Direct Investment Flows to the European Community, 1963-1990," in J. -L. Mucchielli, ed., Multinational Location Strategy, 6 : 29-49.

Coughlin, C.C., Terza, J.V., and Arromdee, V. (1991). State Characteristics and the location of FDI within the United States. Review of Economics and Statistics, 73, 675-683.

Culem, C. (1988). The Locational Determinants of Direct Investment among Industrial Countries. European Economic Review, 32, 885-904.

Cushman, D. (1985). Real Exchange Rate Risk, Expectations, and the Leve1 of Direct Investment. Review of Economics and Statistics, 67(2), 297-308.

Cushman, D. (1987). The Effects of Real Wages and Labor Productivity on Foreign Direct Investment. Southern Economic Journal, 54(1), 174185 .

De Mello, L.R. (1999). Foreign Direct Investment - Led Growth: Evidence from Time Series and Panel Data. Oxford Economic Papers, 51, 133151.

De Mello, L.R. (1997). FDI in Developing Countries and Growth: A Selective Survey. The Journal of Development Studies, 34(1), 1-34. 
Demirhan, E., and Masca, M. (2008). Determinants of Foreign Direct Investment Flows to Developing Countries: A Cross-Sectional Analysis. Prague Economic Papers, 4, 356-369.

Feldstein, M., and Horioka, C. (1980). Domestic Saving and International Capital Flows. Economic Journal, 30, 314-329.

Froot, K.A., and Stein, J.C. (1991). Exchange Rates and Foreign Direct Investment: An Imperfect Capital Market Approach. Quarterly Journal of Economics, 106(4), 1191-1217.

Gold, D. (1989). Foreign Direct Investment. In A. P. Harvey, ed., International Corporate Finance.

Goldberg, M.A. (1972). Determinants of U.S. Direct Investment in the EEC: Comments. American Economic Review, 62, 692-699.

Government of Pakistan, Economic Survey. Islamabad: Economic Advisors Wing Ministry of Finance. (Various Issues).

Green, R. (1972). Political Instability as a Determinant of US Foreign Investment. Bureau of Business and Economic Research Studies on Marketing, No. 7, Austin: University of Texas.

Green, W.H. (1993). Econometric Analysis, (2nd Edition). New York: MacMillan.

Holtz-Eakin, D., Newey, W., and Rosen, H. (1990). Estimating Vector Autoregressive with Pane1 Data. Econometrica, 56, 1371-1395.

Huang, G. (1992). Comparative Analysis of US and Japanese Overseas Direct Investment. Unpublished Ph.D. theses, Pennsylvania: University of Pennsylvania.

Jeon, Y.D. (1992). The Determinants of Korean Foreign Direct Investment in Manufacturing Industries. Weltwirtschaftliches Archiv, 128, 527541 .

Jorgenson, D.W. (1963). Capital Theory and Investment Behavior. American Economic Review, 53, 247-259.

Klein, M.W., and Rosenjgren, E. (1994). The Real Exchange Rate and Foreign Direct Investment in the United States. Journal of International Economics, 36, 373-389. 
Kmenta, J. (1986). Elements of Econometrics, (2nd ed.). New York: MacMillan.

Kok, R., and Ersoy, B.A. (2009). Analyses of FDI Determinants in Developing Countries. International Journal of Social Economics, 36 $(1 / 2), 105-123$

Kravis, I.B., and Lipsey, R.E. (1982). The Location of Overseas Production and Production for Export by US Multinational Firms. Journal of International Economics, 12, 201-223.

Lall, S. (1978). Transnationals, Domestic Enterprises and the Industrial Structure in Host LDCs: A Survey. Oxford Economic Papers, 30, 217-248.

Lee, J.Y., and Mansfield, E. (1996). Intellectual Property Protection and US Foreign Direct Investment. Review of Economics and Statistics, 30, 217-248.

Luger, M. I., and Shetty, S. (1985). Determinants of Foreign Plant Start-Ups in the United States: Lessons for Policymakers in the Southeast. Vanderbilt Journal of Transnational Law, 18, 223-245.

Maddala, G.S. (1977). Econometrics, New York: McGraw-Hill.

Milner, C., and Pentecost, E. (1996). Locational Advantage and US Foreign Direct Investment in UK. Applied Economics, 28, 605-615.

Moore, M.O. (1993). Determinants of German Manufacturing Direct Investment: 1980-1988. Weltwirtschaftliches Archive, 129, 120-138.

Nunnenkamp, P. (1991). Developing Countries' Attractiveness for Foreign Direct Investment, Debt Overhang and Sovereign Risk as Major Impediments? The Pakistan Development Review, 3(4), 1145-1158.

O'Sullivan, P.J. (1993). An Assessment of Irelands' Export-Led Growth Strategy via Foreign Direct Investment, 1960-1980. Weltwirtschaftliches Archive, 129, 139-158.

Onyeiwu, S., and Shrestha, H. (2004). Determinants of Foreign Direct Investment in Africa. Journal of Developing Societies, 20(1-2), 89106. 
Petrochilos, G.A. (1989). Foreign Direct Investment and the Development Process, The Case of Greece, Avebury : Gower Publishing Company Ltd.

Ragazzi, G. (1973). Theories of Determinants of Direct Foreign Investment. IMF Staff Papers, 20(2), 471-499.

Reuber, G. (1973). Private Foreign Investment in Development, Oxford: Clarendon Press.

Root, F. and Ahmed, A. (1979). Empirical Determinants of Manufacturing Direct Foreign Investment in Developing Countries. Economic Development and Cultural Change, 27, 751-767.

Scaperlanda, A.E., and Balough, R.S. (1983). Determinants of U.S. Direct Investment in the E. E. C. Revisited. European Economic Review, $21,381-390$.

Schneider, F., and Frey, B.S. (1985). Economical Political Determinants of FDI. World Development, 13(2), 161-175.

Sekkat, K., and Veganzones-Varoudakis, M.A. (2007). Openness, Investment Climate, and FDI in Developing Countries. Review of Development Economics, 11(4), 607-620.

Wang, Z.Q., and Swain, N.J. (1995). The Determinants of Foreign Direct Investment in Transforming Economies: Evidence from Hungary and China. Weltwirtschaftliches Archive, 131, 359-382.

Wheeler, D., and Mody, A. (1992). International Investment Location Decisions: The Case of US Firms. Journal of International Economics, 33, 57-76.

World Bank (1991). World Development Report, New York: Oxford University Press, Various Issues.

Zhang, K.H., and Maskusen, J.R. (1999). Vertical Multinationals and Host Country Characteristics. Journal of Development Economics, 59, 233-252. 


\section{Appendix}

\section{List of Countries}

\begin{tabular}{|c|c|c|c|c|c|}
\hline 1 & Angola & 25 & Fiji & 49 & Nicaragua \\
\hline 2 & Algeria & 26 & Gabon & 50 & Niger \\
\hline 3 & Argentina & 27 & Gambia, The & 51 & Nigeria \\
\hline 4 & Belize & 28 & Ghana & 52 & Pakistan \\
\hline 5 & Benin & 29 & Guatemala & 53 & Panama \\
\hline 6 & Bolivia & 30 & Guyana & 54 & Papua New Guinea \\
\hline 7 & Botswana & 31 & Haiti & 55 & Paraguay \\
\hline 8 & Brazil & 31 & Honduras & 56 & Peru \\
\hline 9 & Burkina Faso & 33 & India & 57 & Philippines \\
\hline 10 & Burundi & 34 & Indonesia & 58 & Poland \\
\hline 11 & Cameroon & 35 & Iran, & 59 & Senegal \\
\hline 12 & Cape Verde & 36 & Jamaica & 60 & Sierra Leone \\
\hline 13 & Chad & 37 & Jordan & 61 & South Africa \\
\hline 14 & Chile & 38 & Kenya & 62 & Sri Lanka \\
\hline 15 & China & 39 & Korea, Rep. & 63 & Swaziland \\
\hline 16 & Colombia & 40 & Lesotho & 64 & Tanzania \\
\hline 17 & Congo, Rep. & 41 & Madagascar & 65 & Thailand \\
\hline 18 & Costa Rica & 42 & Malaysia & 66 & Togo \\
\hline 19 & Cote d'Ivoire & 43 & Mali & 67 & Tunisia \\
\hline 20 & Czech Republic & 44 & Mauritania & 68 & Turkey \\
\hline 21 & Dominican, Rep. & 45 & Mauritius & 69 & Uganda \\
\hline 22 & Ecuador & 46 & Mexico & 70 & Venezuela \\
\hline 23 & Egypt, Arab Rep. & 47 & Mozambique & 71 & Zambia \\
\hline 24 & E1 Salvador & 48 & Nepal & 72 & Zimbabwe \\
\hline
\end{tabular}

